APL/JHU

QM-78-042R

SEPTEMBER 1978
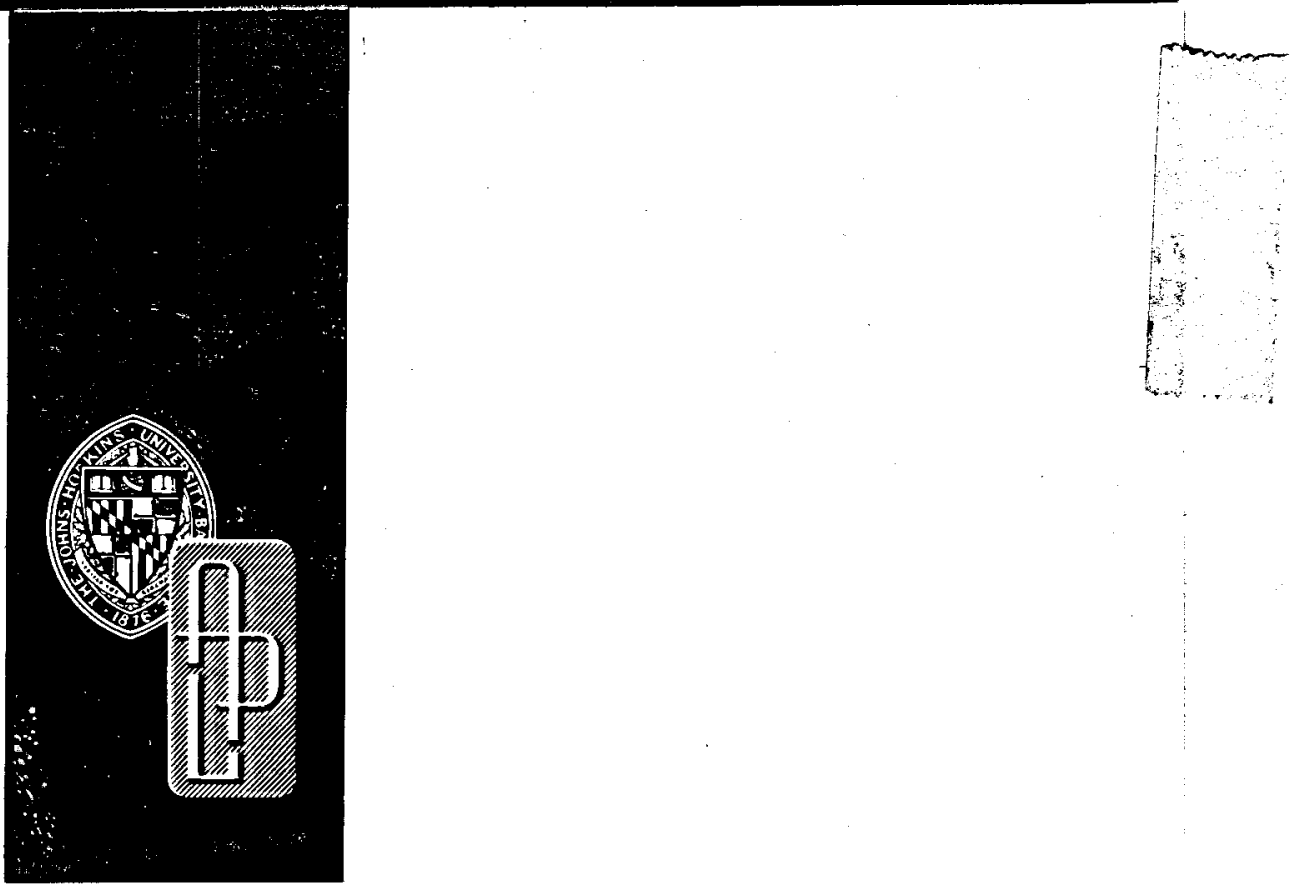

\title{
POTENTIAL APPLICATION OF MADISON FORMATION WATERS FOR COMMUNITY HEATING IN SOUTH DAKOTA
}

Prepared by: R. A. FREEMAN and R. F. MEIER APPLIED PHYSICS LABORATORY THE JOHNS HOPKINS UNIVERSITY JOHNS HOPKINS ROAD LAUREL, MD 20810

For the:

PLANNING BRANCH DIVISION OF GEOTHERMAL ENERGY U.S. DEPARTMENT OF ENERGY 20 MASSACHUSETTS AVENUE, N.W. WASHINGTON, DC 20545

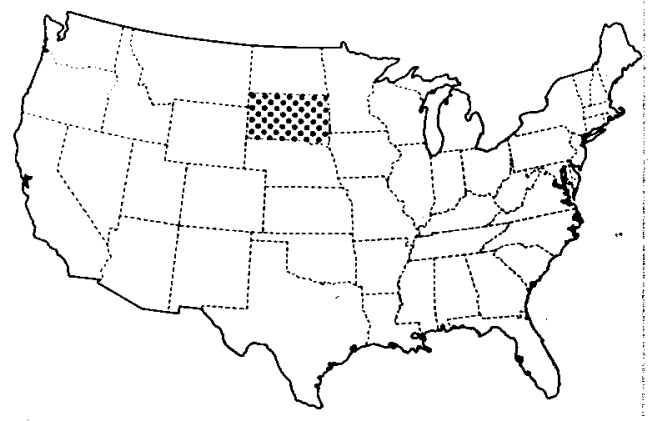

THE JOHNS HOPKINS UNIVERSITY — APPLIED PHYSICS LABORATORY 


\section{DISCLAIMER}

This report was prepared as an account of work sponsored by an agency of the United States Government. Neither the United States Government nor any agency Thereof, nor any of their employees, makes any warranty, express or implied, or assumes any legal liability or responsibility for the accuracy, completeness, or usefulness of any information, apparatus, product, or process disclosed, or represents that its use would not infringe privately owned rights. Reference herein to any specific commercial product, process, or service by trade name, trademark, manufacturer, or otherwise does not necessarily constitute or imply its endorsement, recommendation, or favoring by the United States Government or any agency thereof. The views and opinions of authors expressed herein do not necessarily state or reflect those of the United States Government or any agency thereof. 


\section{DISCLAIMER}

Portions of this document may be illegible in electronic image products. Images are produced from the best available original document. 


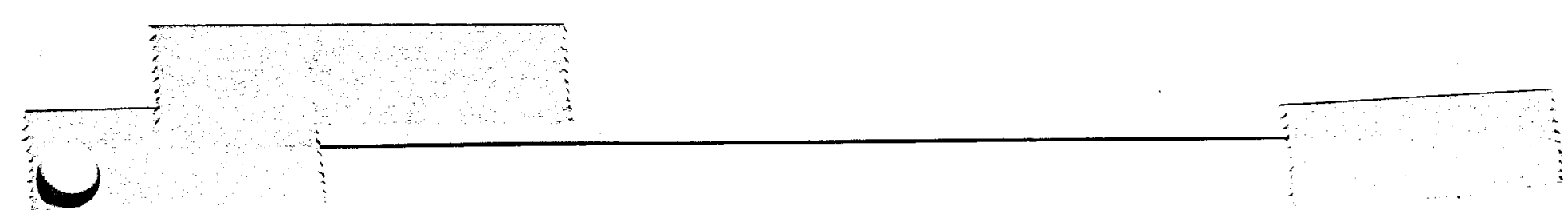

$\mathrm{APL} / \mathrm{JHU}$

QM-78-042R

SEPTEMBER 1978

\title{
POTENTIAL APPLICATION
}

OF MADISON FORMATION WATERS

FOR COMMUNITY HEATING

IN SOUTH DAKOTA

\author{
Prepared by: R. A. FREEMAN and R. F. MEIER \\ APPLIED PHYSICS LABORATORY \\ THE JOHNS HOPKINS UNIVERSITY \\ JOHNS HOPKINS ROAD \\ LAURE L, MD 20810 \\ For the: PLANNING BRANCH \\ DIVISION OF GEOTHERMAL ENERGY \\ U.S. DEPARTMENT OF ENERGY \\ 20 MASSACHUSETTS AVENUE, N.W: \\ WASHINGTON, DC 20545
}


The Applied Physics Laboratory of the Johns Hopkins University, in its role as Regional Operations Research Contractor to the Planning Section of the Division of Geothermal Energy, Department of Energy, examined the potential for geothermal energy applications in the state of South Dakota. This report was written to bring together all of the considerations for the application of the Madison Formation waters for space heating. The report is intentionally brief. It was written primarily for the information and the use of the people in South Dakota. These data should encourage them to take the initiative, individually or collectively, to develop further their natural resource. If additional data or assistance is required, the reader is referred to the following agencies:

The South Dakota State Energy Office Pierre, SD 57501

Fifth District Planning and Development Commission P.O. Box 640

Pierre, SD 57501

Sixth District Council of Local Governments P.0. Box 1586

Rapid C1ty, SD 57709

Idaho National Englneering Laboratory

Operations Office

Box 1625

Idaho Falls, ID 83401

Department of Energy

Division of Geothermal Energy

Washington, DC 20545

We acknowledge the considerable assistance of many organizations and Individuals in South Dakota, notably: Dr. Duncan McGregor of the State Geological Survey; Scott McGregor of the State Planning Bureau; Gerald Bergum of the Fifth District Planning and Development Commission; Van Linquist and Brian Shorten of the Sixth District Counc1l of Local Governments; G. Stroppe1, President of the Midland Town Counc11; John Iszler, Superintendent of Schools in Edgemont; Charles Maxon, Superintendent of Schools in PhIlip; Arthur D. Thomas, former Administrator, and William Allison, present Administrator, of St. Mary's Hospital in Pierre. 
CONTENTS

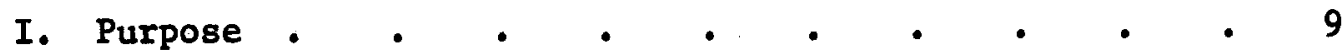

II. INTRODUCTION • • • . • . • . . 10

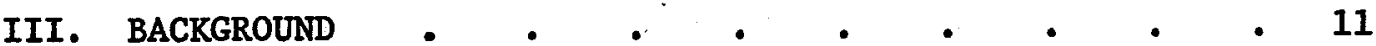

A. National Approach to Developing Geothermal

Resources . $\quad . \quad \cdot \quad \cdot \quad \cdot \quad \cdot \quad$. 11

B. National Geothermal Energy Goals . . . 11

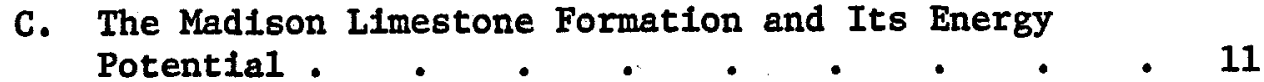

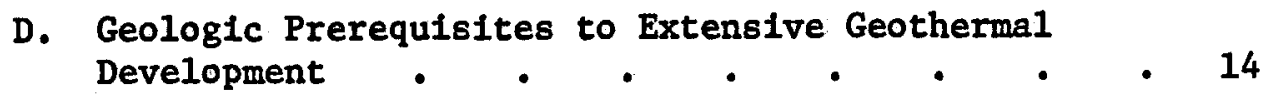

IV. Demography and Energy Use in the Madison Area . 16

A. Demography . . . . . . . . 16

B. Energy Use • $\quad$ - . . . . . 16

V. Potential Geothermal Application of the Madison

Aquifer . • . • • • • • •

Description of Community Heating System . . • . 17

A. Cost Analysis . • . . . . . . 17

The supply well (and reinfection if required) $\quad 19$

The central heat exchanger . . . . . 19

Town distribution system . . . . . . 19

Individual connections to municipal system . . 21

B. Illustrative Example . • . . . . 21

Energy demands. $. \quad . \quad . \quad \cdot \quad \cdot \quad \cdot \quad \cdot 21$

C. Cost Model Assumptions . . . . . . $\quad$. 21

D. Cost Model Results . • . . . . . 24

VI. Financing Geothermal Projects . . . . 27

A. Department of Energy _ . . . . . 27

1. Grant and Cost-Sharing Programs . . . 27

a. PRDA - . • . . . . 27

b. PON - ... .28

2. Loan Guaranty Program . . . . . 28 
B. Department of Agriculture - . . . . 28

1. Community Facilities Loans . . . . 29

2. Home Mortgage Loans - . . . . 29

C. Department of Housing and Urban Development . . 29

VII. Technical and Administrative Assistance . . . 30

A. Universities • . . . . . . . 30

B. District Planning Councils . . . . . 30

C. Water Conservancy Subdistricts . . • . 30

VIII. Legal Issues and Laws . . . . . . . . 31

A. Water Use $\quad$. $\quad$. . . . . 31

1. Restrictions . . . . . . . 31

2. Proposals and Permits . . . . . 31

B. Appropriation of Water Use . . . . . . 32

C. Beneficlal Use of Water . . . . . . 32

D. Withdrawal from Aquifers . . • . . . 32

E. Status of Indian Reservations . . . . 33

IX. Bibllography • • . . . . . . . $\quad$ - 34

APPENDIX A, Geothermal Space HeatIng Cost Model . . 35

System Design Parameters for Residential Space

Heating . . . . . . . . . . 36

Central Heat Exchanger Design . . . . . 37

Residential Heating Coll Design . . . . . 38

Well Costs • • • • . . . . . 39

Pipe and Installation Costs . . . . . . 40 
1. Region of interest to USGS/WR and temperatures in the Madison

2. South Dakota Madison geothermal space heating system . . . . . . . . . . . . 18

3. Double pipeline transmission system in western South Dakota; insulation only on feedline . . $\quad 20$

4. Single (uninsulated) pipeline in western South Dakota (for reinjection) . . . . . . 22

5. Total geothermal space heating cost . . . . 23

6. An example of the cost model for a town with a population of 1000 (with a reinjection well) . . 23

7. South Dakota Madison geothermal space heating cost model

8. Towns for which geothermal space heating is economically feasible 
The primary purpose of this report is to call attention to the possibility of using natural underground hot water in South Dakota for community space heating and to assist citizens, governing bodies, and advisory groups in considering this geothermal energy as an alternative to the other forms of energy (mainly fuel oll and propane gas) widely used today for space heating.

Secondary purposes are to explain the role of the federal Department of Energy in developing the use of alternative sources of energy, to suggest possible funding assistance to communities and individuals in changing from their present energy base, and to call attention to legal and furisdictional factors that need to be considered in making such changes. 
The Madison Limestone Formation (the Madison) that lies beneath the western half of South Dakota contains large amounts of hot water at temperatures between 120 and $160^{\circ} \mathrm{F}\left(49\right.$ and $\left.71^{\circ} \mathrm{C}\right)$. Much of the water is potable and has been used by some communities and individuals for many years. A few isolated projects (e.g., Midland High School and St. Mary's Hospital in Pierre) exist or are under way to employ the waters for space heating. These projects, however, w1ll use only a very small fraction of the energy resource.

The geology of the Madison is reasonably well known and this knowledge is being advanced further by state and federal studies. Thus it can be stated that the waters of the Madison represent a geothermal resource that is avallable today to the citizens of western South Dakota. Furthermore, no new technology is required to tap this energy source, so that it is possible to develop it in a relatively short time.

Because South Dakota lacks local fossil fuels and transportation systems for coal and gas (except in some border areas of the state) it is desirable to develop available alternative energy forms that surmount these difficulties. As early as 1974 the state suggested using the geothermal potential within its borders (cf, S. D. Geologic Survey Publication No. 110).

This report suggests that the most practical early application of the Madison waters is in community space heating using a procedure patterned after the Rural Electric Administration's pioneering efforts in electrification; that is, local hot waters should be considered as a municipal commodity. The general design of such a community system is discussed along with its cost, means of $\mathrm{fi}_{1-}$ nancing, and Iife expectancy. Legal questions and state statutes that are pertinent are cited and the life expectancy of the entire Madison resource and equipment to exploit the resource are considered. 


\section{A. National Approach to Developing Geothermal Resources}

The Division of Geothermal Energy (DGE) was established in 1974 ss part of the U.S. Energy Research and Development Administration (ERDA), now the Department of Energy. DGE's activities include geothermal research and development, feasibility demonstrations, and issuance of grants in specific areas.

Through operations research contractors, DGE identifies sources and potential uses of geothermal energy and prepares scenarlos for the public and private development of the resources.

As one of the DGE operations research contractors the Applied Physics Laboratory of The Johns Hopkins University (APL) examined available information on the Madison and prepared an initial scenario for the development of the aquifer. Because of its temperature and availability an important application is commercial and residential space heating. The Idaho National Engineering Laboratory is continuing the evolution of the scenario.

\section{B. National Geothermal Energy Goals}

The goal of DGE is to establish geothermal energy as an economical, environmentally clean alternative to fossil fuel energy and thus help to satisfy the constantly increasing national energy demands. DGE anticipates that all U.S. geothermal resources will provide about $0.6 \times 10^{15}$ Btu of energy per year by 1975 and $18 \times 10^{15}$ Btu per year by 2020. Current total U.S. energy consumption is $70 \times 10^{15}$ Btu per year (cf, DOE/DGE Program Goals). Thus it is seen that geothermal energy is not expected to contribute significantly to the total national demand within the next few years, but eventually will do so and thus reduce the need for fossil fuels.

Of the five primary types of geothermal energy (hydrothermal, geopressured, hot dry rock, magma, and normal gradient) the first is of initial interest to South Dakota.

C. The Madison LImestone Formation and Its Energy Potential

The Madison is a well known aquifer that underlies portions of South Dakota, North Dakota, Montana, and Wyoming. In South 
Dakota it extends beneath the western half of the state. The entire aquifer covers an area of about $25000 \mathrm{mi}^{2}$ and stores an estimated $10^{9}$ acre-ft of water. The water temperatures are considered moderate, ranging from about 120 to $160^{\circ} \mathrm{F}\left(49\right.$ to $\left.71^{\circ} \mathrm{C}\right)$. Figure 1 is taken from the U.S. Geological Survey Water Resources Investigation 63-75, and shows temperature data points for the Madison. Note that the temperatures are given in degrees Celsius. Note, also, that the temperature tends to increase as one moves east from the Black Hills area.

Surface waters in the Black Hills, B1g Horn, and Laramie Mountains are belleved to recharge the Madison aquifer at the rate of about 150000 acre-ft per year.

The average age of the Madison waters is estimated by U.S. Geologic Survey/Water Resources to be between 15000 and 30000 years and the waters reside in a limestone formation averaging 400 $\mathrm{ft}$ in th1ckness and at modest depths ranging from 2000 to $6000 \mathrm{ft}$ in South Dakota. The porosity of the formation averages $8 \%$; the transmissivity is estimated to be $0.013 \mathrm{ft}^{2} / \mathrm{s}$ and the storage coefficient is estimated to range from 0.0001 to 0.00025 (South Dakota School of Mines Report, "The Geothermal Applications on the Madison Aquifer System (Pahasapa) in South Dakota," 1976). The values of these parameters indicate to reservoir engineers that adequate flow rates can be maintained without depletion of the aquifer.

The ability of the aquifer to transmit water is quantitatively described by its transmissivity. Transmissivity is the rate at which water passes through a unit width of the aquifer under a unit hydraulic gradient (Lohman and others, 1972). The storage coefficient is a dimensionless number that is the ratio of the volume of water that an aquifer releases from or takes into storage per unit surface area of the aquifer per unit change in the hydraulic head (pressure) (Lohman and others, 1972).

The southern region of the Madison contains water that is generally potable with dissolved solids of 1000 to $2000 \mathrm{ppm}$. To the north the water becomes more saline and less potable. Dissolved solids are as high as 6000 ppm near the North Dakota border; this presents problems in direct use of the water.

Detailed discussions of the Madison's geology and its geothermal potential are available in a series of publications by the South Dakota Geologic Survey (of particular interest is the Report of Investigations No. 110). The report by the South Dakota School of Mines and Technology "Geothermal Applications on the Madison Aquifer System (Pahasapa) in South Dakota," 1976 is also Important. 
To estimate the geothermal potential of the Madison for community space heating (or other purposes where the assumptions apply) in western South Dakota the following assumptions are considered: the average water temperature is $140^{\circ} \mathrm{F}$, water is withdrawn at the natural recharge rate of 150000 acre-ft per year, and the load refection temperature (water temperature at the end of the process) is $100^{\circ} \mathrm{F}$. On this basis, the quantity of energy available is $16 \times 10^{12} \mathrm{Btu}$ - the equivalent of 2.7 million barrels of oil per year.

\section{Geologic Prerequisites to Extensive Geothermal Development}

Although the Madison can be used for space heating and other applications much more widely than it is today, several important factors must be better known before extensive geothermal development can be shown economically practicable. These factors, 1isted below, require the collection of basic and definitive engineering data relating to the Madison itself and to other aquifers that may interact with the Madison.

\section{The heat source and Its life expectancy}

South Dakota is a stable tectonic region and thus it is considered probable that the thermal properties of the Madison waters w111 remain essentially constant for a long time. However, the exact nature of the heat source that ralses the water temperature above that found at equal depths in most other regions of the United States is not yet known. In Goguel's book Geothermics, the source is suggested to be a concentration of trace radioactive elements in the Precambrian granite that covers the Madison formation. If this is true then the natural diminution of water temperatures is expected to be very slow, measured in tens of thousands of years. The USGS/WR Madison Study (In progress) should resolve the question of heat source and better predict the expected life of the Madison as a geothermal resource.

\section{Madison parameters}

Factors that affect drilling and withdrawal of water are well known in various regions but not for all parts of the Madison that are of interest. These-factors include the aquifer thickness, porosity, permeability, potentiometric head (artesian pressure), temperature, and-depth below ground level. USGS/WR work and planned work of the-School of Mines will help to develop these data. Add1tional-assistance may be avallable through the resource engineering program of the Division of Geothermal Energy of the Department of Energy. 


\section{Effects of substantial withdrawal}

Broad use of the water can affect the aquifer thermal properties, quality of water, and artesian pressure. In turn, such changes would affect the annual cost of a heating system by demanding higher flows, more rapid cleaning or replacement of components, and possible installation of pumps.

Currently USGS/WR is developing (as outlined in Report 75-631) a detailed and quantitative model of the hydrology in the Madison aquifer and other aquifers that can affect its flow. Although postponed by recent congressional action, the Wyoming proposal to use Madison water to move coal via a slurry plpeline from the Powder River Basin is of particular interest. DGE is negotiating to have the study extended so that proposed Madison usage in South Dakota would be included. A letter of intent has been written and proposes a joint effort by DOE/DGE, the state of South Dakota, and USGS to collect the additional data needed to properly represent South Dakota use of the Madison waters (letter from U.S. Department of Interior Geologic Survey, April 1977).

4. Thermodynamic model of aquifer

A model of the aquifer that includes the western South Dakota region of the aquifer needs to be developed so that various rates of withdrawal and locations of withdrawal can be examined with respect to cooling the aquifer, well-to-well artesian effects, or the need to reinject water after use. The USGS model should be carefully examined to see if it would be adequate or could be modified for South Dakota's purposes. 
IV. DEMOGRAPHY AND ENERGY USE IN THE MADISON AREA

\section{A. Demography}

In western South Dakota, where the Madison aquifer is relatively shallow and its geothermal waters are readily available, 117000 persons occupy 45000 residences (excluding Rapid City). of this population within the boundaries of the Madison, about 74700 live in rural areas with an average density of 2 persons per square mile. The remaining 42300 live in communities of varying size: 18 with 10 to 100 persons, 44 with 100 to 1000 persons, 6 with 1000 to 2000 persons and 2 with 2000 to 10000 persons.

\section{B. Energy Use}

The total commercial and residential (non-electric) energy consumption in South Dakota during 1973 was $54.2 \times 10^{12} \mathrm{Btu}$ (equivalent to 9.4 million barrels of o11). In decreasing order of importance this energy was supplied by natural gas, oil, LPG, electricity, and coal. In the Madison region the resources were o1l, LPG, electricity, and coal.

Assuming that energy consumed per capita was uniform throughout the state, the $17 \%$ of the population 1iving in the Madison region consumed $2 \times 10^{8}$ Btu per residence for a total of $8.3 \times 10^{12}$ Btu (the equivalent of 1.6 million barrels of ofl). For those living in towns with populations greater than 10 the consumption was $3.2 \times 10^{12}$ Btu. 
v. POTENTIAL GEOTHERMAL APPLICATION OF THE MADISON AQUIFER

The preceeding sections have defined the Madison aquifer as a geothermal resource that is being used for a few space heating projects. This application has much broader uses.

In addition, geothermal energy is a clean source with few environmental disadvantages and, since it is indigenous to the state, its use could reduce the problems that accompany the almost complete dependence on imported fuels: shortages, distribution, and increasing prices.

Therefore, It is suggested that communities consider developing local systems that tap the Madison and use the energy of the hot waters primarily for heating homes, but including other buildings as would best meet a community's needs.

The key question in considering this conversion is whether or not the community (ultimately its citizens) can afford the costs. Unless the monthly costs (capital amortization, maintenance, etc.) to a subscriber can be less than current and projected costs of conventional fuel systems the subscriber cannot be expected to be interested in converting to geothermal energy use.

To answer this question a cost model for a community geothermal space heating system shown in Fig. 2 was developed (see Appendix A) and is used to show, in terms of town population, where the system may be cost competitive with fossil fuels.

\section{DESCRIPTION OF COMMUNITY HEATING SYSTEM}

\section{A. Cost Analysis}

The geothermal space heating system is divided, for cost modeling puposes, into four main components (cf, Fig. 2);

1. Geothermal we11,

2. Heat exchanger and central facllity,

3. Two-way transmission from production well to community, and 


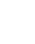

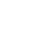


4. Community distribution system (two-way pipe line, residence hook-up, and conversion of home heating system).

The Supply well (and reinjection if required)

Based on current prices (cf, Appendix A) the cost of drilling, casing, and enclosing a 7 . In. diameter well drilled $3800 \mathrm{ft}$ into the Madison formation was estimated by Franc1s-Meador-Gellhaus, Inc., to be about $\$ 155000$. This figure is used to calculate total community costs in an illustrative example below. Such a well is assumed to be artesian and have a flow rate of $1300 \mathrm{gal} / \mathrm{min}$.

The central heat exchanger

A central heat exchanger is used to transfer heat from the well water to a secondary closed-1oop system containing treated water and to increase the overall system reliablifty. A stainless steel, plate-type heat exchanger with removable covers (to permit ready access for periodic inspection and cleaning) was selected. This type is considered to be extremely reliable and so a back-up exchanger should not be required.

The cost of the heat exchanger is directly proportional to the plate (surface) area, which, in turn, is proportional to the heating demand. Thus, given the population and heating demand, the per capita cost of the heat exchanger is readily determined.

To allow for growth it is assumed that the central exchanger for a community is designed with $35 \%$ excess capacity.

\section{Town distribution system}

The required cross-sectional area of the transmission pipeIine is directly proportional to the population it serves. Similarly, the cost per unit length of Installed pipeline is approximately a linear function of the cross-sectional area of the pipe. It follows that pipeline costs are directly proportional to the population served and, thus, per capita cost can be determined. Similarly, average cost per residence can be determined using the average of 2.6 occupants per residence.

Figure 3 shows installed costs per mile for the closed-10op, two-way distribution line. Costs include those for cement-asbestos pipe, trenching to bury the pipe $5 \mathrm{ft}$ deep, on-site application of 1 In. foam insulation on the feedline, refilling the trench and compacting the refill soil only where the line intersects roads. Compacting was assumed to be required over $15 \%$ of the 1ine. Specific costs are shown for installation of production size pipes as well 
THE JOHNS HOPKINS UNIVERSITY APPLIED PHYSICS LABORATORY

LAUREL, MARYLAND
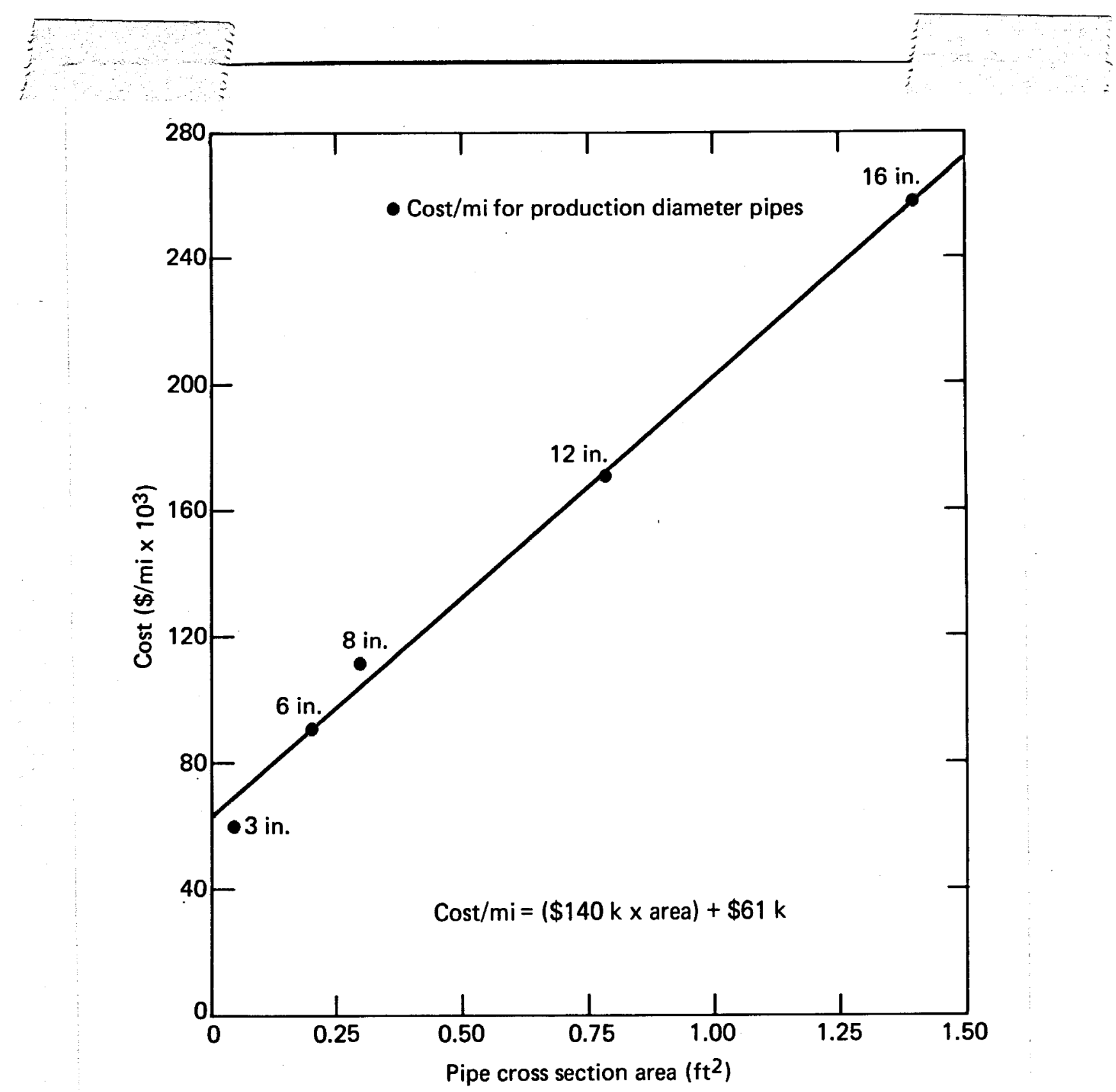

Fig. 3 Double pipeline transmission system in western South Dakota; insulation only on feedline. 
as the straight line approximation used in this paper for estimating system costs.

Figure 4 shows the installed costs per mile for a one-way line, uninsulated, to a reinjection well which might be required.

Individual connections to municipal system

Residential hook-up charges and conversion, including the local heat-exchanger using the closed-loop heating fluld, are fixed costs per household and thus can be put on a per capita basis.

B. Illustrative Example

Figure 2 illustrates the total costs for a particular town (Midland, SD, with a population of 312) with the production well $1 \mathrm{mi}$ from town and no reinjection well.

\section{ENERGY DEMANDS}

The design requirements, both peak heating and average seasonal demands, were determined for weather conditions existing in western South Dakota and the type of housing in Midland. The peak heating demand for 120 residences was estimated to be $9.9 \times 10^{6}$ $\mathrm{Btu} / \mathrm{h}$, including $10 \% 10$ sses and $10 \%$ margin for growth. The distribution system consists of an 8 in. main plpe and 4 in. feeder lines. Houses were assumed to be uniformly distributed through the town area for estimating the required pipe lengths. All homes were considered to be converted from a conventional forced-air system by installation of a heat exchanger.

C. Cost Model Assumptions

Using the estimated component costs and scaling above and below the population in the Midland example, monthly per capita costs for conversion were calculated.

The general form of the cost model is shown in Fig. 5 and the specific values for a town with a population of 1000 are shown in Fig. 6.

In these calculations it is assumed that all homes initially had forced-air systems. This is true in general, but can be far from correct in some communities where newer homes may be using electricity for all domestic purposes. Conversion from all-electric to geothermal 1s not considered in the model because the cost to the homeowner would be prohibitively high. Conversion from oll- or 
THE JOHNS HOPKINS UNMERSTY APPLIED PHYSICS LABORATORY LAUREL. MARYLAND

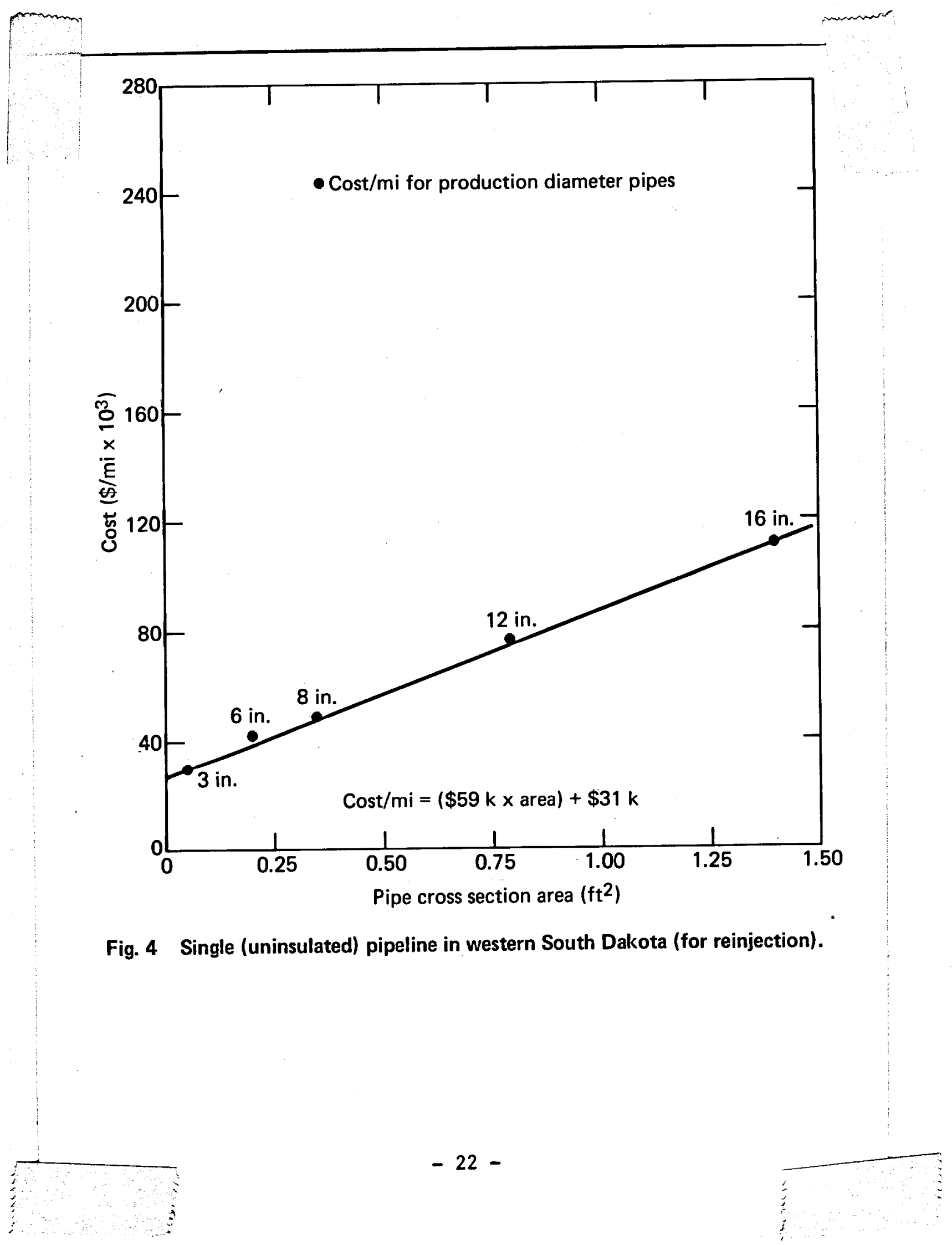




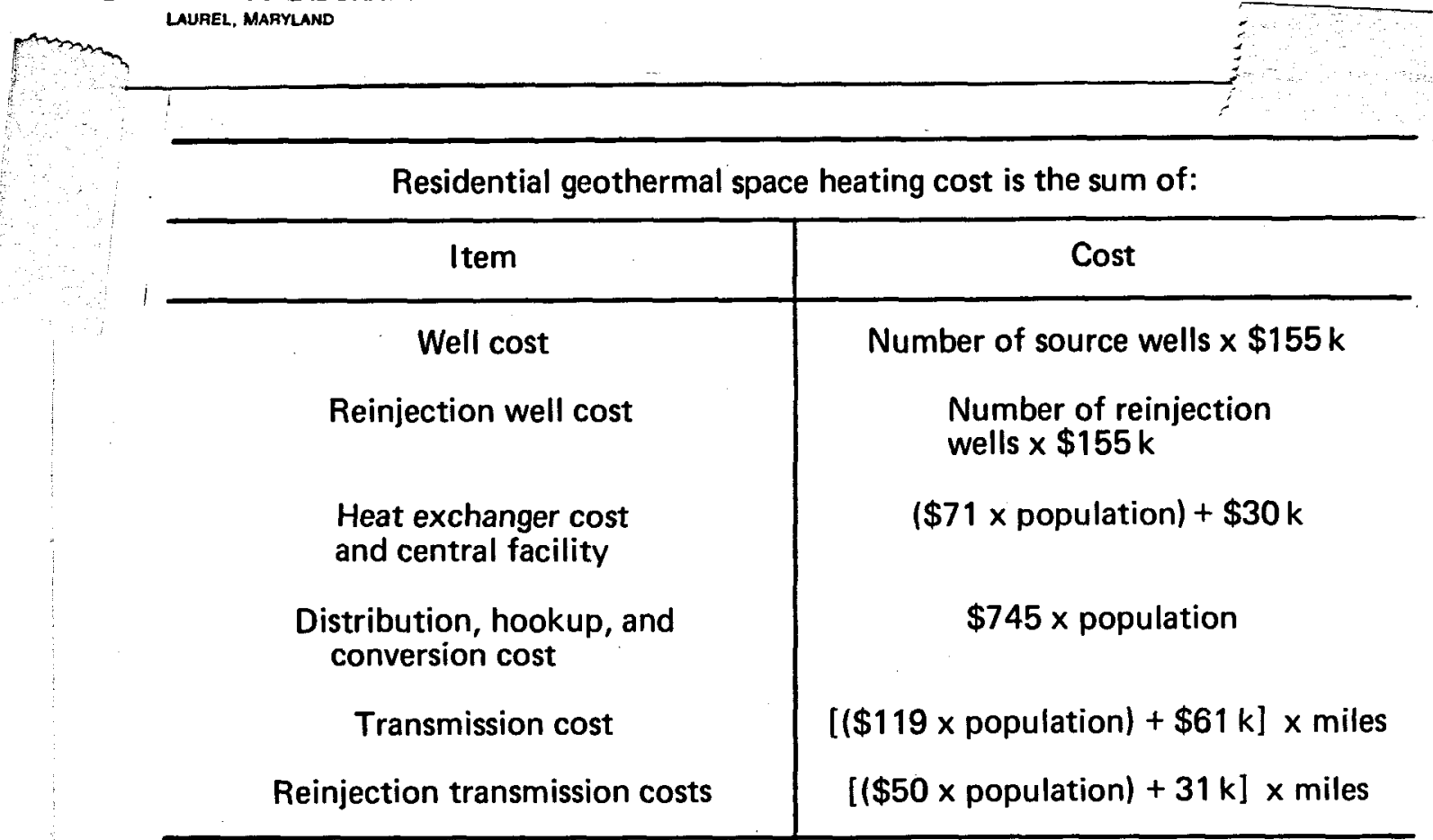

Number of source wells $=$ integer value of $(1.72 \times$ population $\div 1300)$

Number of reinjection wells $=$ integer value of $(0.86 \times$ population $\div 1300)$

Fig. 5 Total geothermal space heating cost.

Transmission distance $=2 \mathrm{mi}$

Transmission distance to reinjection well $=1 \mathrm{mi}$

Well cost $=2$ wells at $\$ 155 k$ per well $=$ $\$ 310 k$

Reinjection well cost $=1$ well at $\$ 155 k$ per well $=\quad \$ 155 k$

Heat exchanger cost $=(\$ 71 \times$ population $)+\$ 30 k=\quad \$ 101 k$

Distribution, hookup, and conversion cost $=(\$ 745 \times$ population $)=\$ 745 \mathrm{k}$

Transmission cost $=[(\$ 119 \times$ population $)+\$ 61 \mathrm{k}] \times$ miles $=\quad \$ 360 \mathrm{k}$

Reinjection transmission cost $=[(\$ 50 \times$ population $)+\$ 31 \mathrm{k}] \times$ miles $=\$ 81 \mathrm{k}$

$$
\text { Total cost } \overline{\$ 1752 k}
$$

Fig. 6 An example of the cost model for a town with a population of 1000 (with a reinjection well). 
LPG-fired, forced-air furnaces, however, is relatively inexpensive since existing ducts would be used for hot air distribution.

The converstion cost ( $\$ 795$ per house) includes bringing the hot water into the house, the home heat exchanger, inserting the heat exchanger into the distribution ducting, thermostat, and wiring for automatic control.

The fixed monthly costs, assumed to be $15 \%$ per year, include capital amortization, maintenance, and services.

Conventional fuel costs is an average of 1977 prices of fuel oil and liquid propane weighted by the amount of each fuel used for space heating.

D. Cost Model Results

Figure 7 is a plot of the cost model results. It 1llustrates that geothermal space heating systems become competitive with conventional systems for communities of about 250 persons or more. If reinjection is required the population would have to exceed 300 . Reinfection will be desirable or mandatory for many communities, therefore the larger of the two preceding populations is the more likely dividing line for fudging economic utility.

Figure 8 lists the South Dakota towns and cities that lie within the Madison boundaries and which have populations of 300 or more. Each of these communities, provided that its current and predominant heating is forced-air, appears to be a likely candidate for geothermal space heating conversion. The ever-present possibility of oll embargoes, increases in fossil fuel prices, and continuing devaluation of the dollar tend to make the conversion appear even more attractive. 


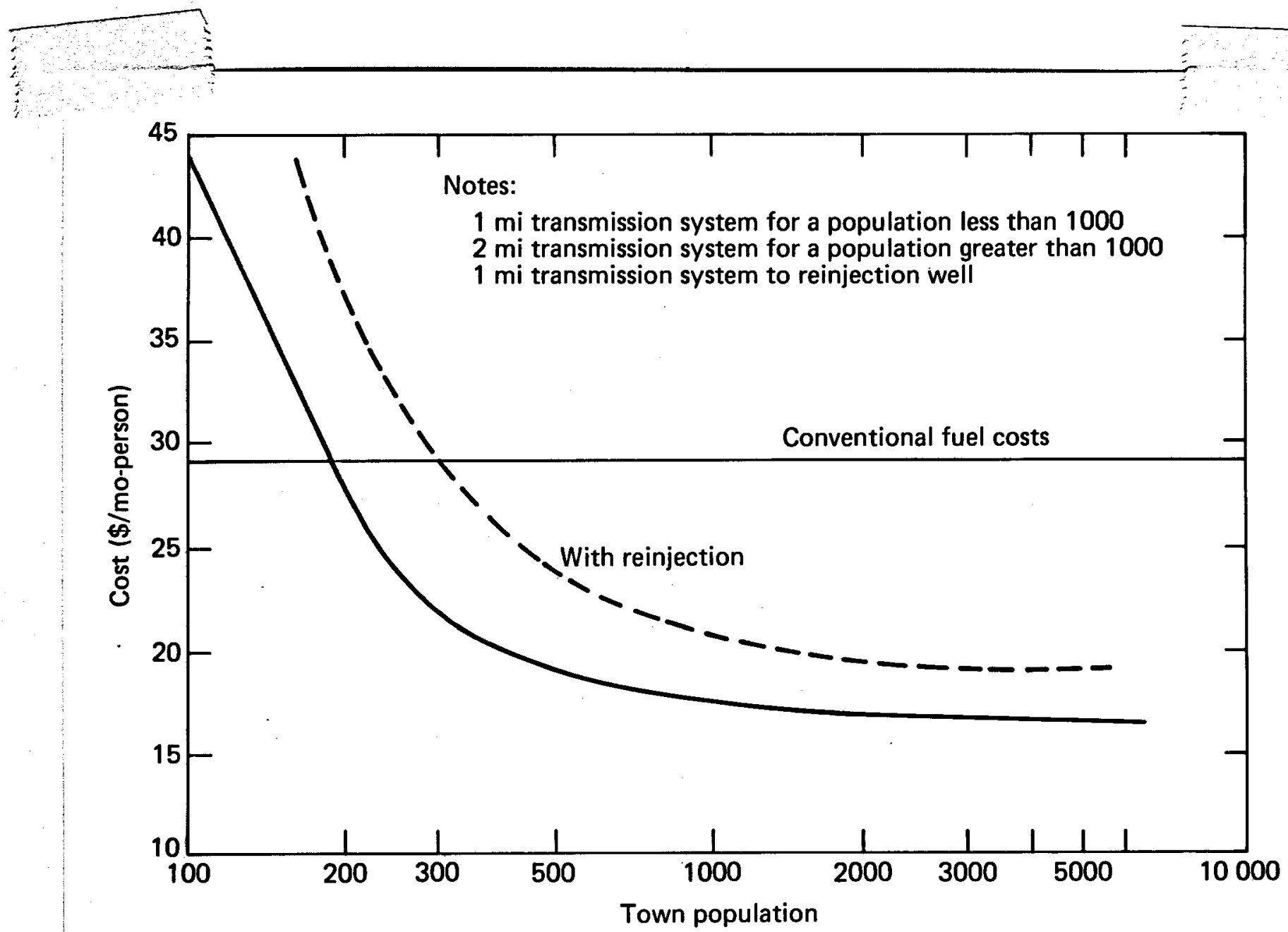

Fig. 7 South Dakota Madison geothermal space heating cost model. 


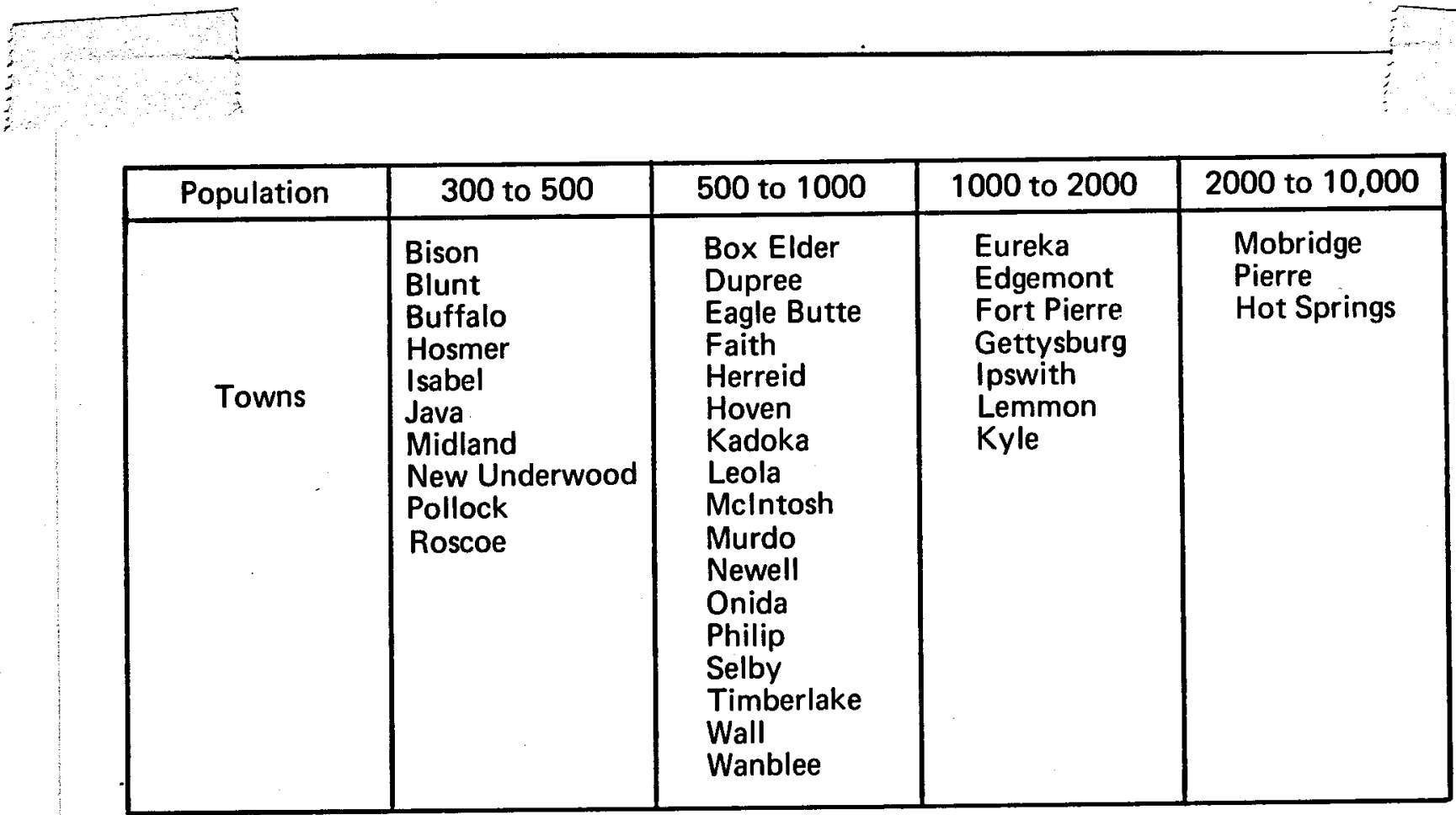

Fig. 8 Towns for which geothermal space heating is economically feasible. 
As discussed in previous sections, the Madison is one of the better known geothermal resources in the United States. Hot water of good quality is avallable readily in many locales while in others, particularly in the northwestern part of the state, more precise reservolr and well data are needed and some innovative technology will probably be needed to demonstrate how their more corrosive waters might be exploited economically.

In these latter areas projects are better classifled as developmental or demonstration rather than production and federal assistance may be available through Department of Energy grants or cost-sharing programs discussed below.

In all locales, communities that are contemplating geothermal space heating conversions are faced with project costs on the order of several million dollars. The most appropriate financing procedure may be municipal bond issues; for others, conventional loans. The federal government, through several of its Departments, offers assistance in loans and the guaranty of loans. Some of the more promising possibilities are cited below.

\section{A. Department of Energy}

\section{Grant and Cost-sharing Programs}

DOE provides grants and participates in cost-sharing programs to a limited extent for geothermal projects in the private sector. Projects of interest are made known to the public by Program Research and Development Announcements (PRDA) and Program Opportunity Notices (PON).

\section{a. PRDA}

Each PRDA solicits proposals for studies and analyses that w111 lead to new and Improved technology for extracting and utilizing energy from geothermal resources. PRDAs are issued from the DOE San Francisco Operations Office and provide sharing of costs when a proposer could benefit independently from participation in a project. State, municipal, or noncommercial applicants are chosen on a competitive basis. 
As examples, the South Dakota School of Mines and Technology responded to a 1976 PRDA and won support for a 12 month study of the Madison aquifer; the Edgemont School District responded to a 1977 PRDA and won support for designing a geothermal system for space heating its local school complex.

b. PON

A PON solicits proposals for geothermal field experiments and applications that will demonstrate the adequacy of the reservoir as well as provide technical and economic data, and will address legal, environmental, and institutional issues for assessing the practlcability of further resource usage. PONs are issued from the DOE San Francisco Operations Office. Applicants are selected competitively and projects are funded through federal and local cost-sharing.

of 22 proposals submitted in response to a 1977 PON, 8 were selected ( 4 in South Dakota). The 4 in South Dakota were to the School of Mines and Technology for heating ranch buildings and agriculture uses; to the community of Box Elder for heating the Douglas School complex; to the Haakon School District for heating school buildings in Phillip; and to the St. Mary's Hospital in Pierre for space heating the hospital and nelghboring business structures.

\section{Loan Guaranty Program}

This program is intended to assist lenders in the private sector by guarantying them against loss of principal or interest on loans made for evaluating potential of geothermal reservolrs, for research and development in the technology of extracting and utilizing resources, for obtaining rights in resources, and for developing, constructing, and operating geothermal energy producing facilities.

The DOE San Francisco Offlce is responsible for supplying information on the program and for analyzing guaranty applications from South Dakota.

\section{B. Department of Agriculture}

Consultation with the Assistant Secretary of Agriculture for Rural Development established that the most appropriate partic1pation of this department in a geothermal project would be for a loan or loan guaranty after engineering design and specifications I for the project have been completed. Such loans or guaranties would be requested through the department's Farmers Home Administration. 
1. Community Facilities Loans

Low interest (currently 5\%) loans are made to qualifying communities for projects that supply essential facilities to rural residents. The funds are administered by the community. Applications for loans are made through the local Farmers Home Administration County Office.

2. Home Mortgage Loans

Moderate interest (currently $8.25 \%$ ) loans to home owners are available for various types of improvement. The interest rate would be considerably lower for occupants of subsidized housing. Applications are made through the local Farmers Home Administration County Office.

C. Department of Housing and Urban Development

Block grants are available to towns on the basis of (a) home rehabilitation and (b) upgrading the standard of a utility. As above, grants would be for well engineered projects and any community grant application would be in competition with all other applications within the HUD region (region 8 for South Dakota). A major consideration in awarding grants is the inclusion of low income housing. 
VII. TECHNICAL AND ADMINISTRATIVE ASSISTANCE

Few of the communities in the Madison area have the total resources needed to undertake a geothermal space heating project on their own; cooperation with and assistance from other state organizations and institutions w11l be mandatory. The primary ones and their areas of contribution are listed below.

\section{A. Universities}

The universities and colleges in South Dakota have been and w111 continue to be major contributors to the science and technology of geothermal application. The State University has established an Energy Department recently, and the School of Mines and Technology has been very active in geothermal research for some time. The latter institution has completed its comprehensive study and survey of the Madison with primary emphasis on space heating. This report, in addition to assistance already given to several communities, establishes the school as an effective state resource for developing further plans and proposals for geothermal heating.

\section{B. District Planning Commission}

The 5th and 6th District Planning and Development Commissions can provide administrative assistance to communities by informing them of available grants and cost-sharing programs for geothermal energy profects as well as working with community personnel to assure proper filing procedures. Legal advice is also available in the councils.

\section{Water Conservancy Subdistricts}

These organizations are concerned with surface and ground water Issues, water conservation, and future water prospects for their areas of responsibility. Therefore, they should be aware of and Involved in programs that tap major water sources so as to advise on handling waste water and on long term effects. The Black Hills Subdistrict, for example, has been consulted and has stated its Interest and willingness to participate in geothermal project planning and development. 
Title 46 of the South Dakota Compiled Laws (SDCL 1967) addresses waters and water rights in the state. Chapter 46-6, specifically, Is concerned with ground water and wells and clearly defines ground water as water under the surface of the ground "whatever may be the geologic reservoir in which it is standing or moving" (46-1-6). Artesian water and wells are included as one category of ground water and wells.

New statutes and amendments to previous statutes enacted through 1977 reflect interest in broader applications of ground water, but there is no specific reference to use of the heat content of ground water for beneficlal use. Although it might appear that such water use is permitted by the existing South Dakota Laws, it is a point that legislators may be required to address explicitly.

\section{A. Water Use}

The people of the state have a paramount interest in the use of the state water but the state determines what water can be converted to public use (46-1-1) and the ways it should be developed for the greatest public benefit (46-1-2). Both surface and underground waters are listed explicitly. Section 46-1-3 declares that all water within the state is the property of the people but that the right to use may be acquired by legal appropriation. Furthermore, domestic use of the water takes precedence over appropriative rights (46-1-5) and the use of ground water by municipal systems is defined as domestic use $(46-1-6)$.

\section{Restrictions}

A 1972 amendment (46-1-2) specifically 1imits the quantity of Impounded water that can be withdrawn annually: it shall not exceed the quantity of the average estimated annual recharge.

\section{Proposals and Permits}

Proposals for the appropriation of ground water are submitted to the State Water Rights Commission for approval (46-6-3) prior to the Issuance of well drilling licences (46-6-9). The commission is authorized (46-6-6-1) to adopt special rules for large capacity wells. As more precise data from test Installations become avallable the commission should be able to further refine these rules and, as needed, have them submitted for Inclusion in the legal code. 


\section{B. Appropriation of Water Use}

Domestic use of ground water, when the user is a family, is one exception to the requirement for filing a proposal for appropriation to the State Water Rights Commission. Only notice of intent needs to be given. However, municipalities, nonprofit rural water supply companies, and sanitary districts must file a proposal. If the proposed usage rate 18 greater than 10000 acre-ft per year, the commission must submit the proposal to the State Legislature for approval. This rate $\left(33 \times 10^{8} \mathrm{gal} / \mathrm{yr}\right)$ is 5 to 8 times greater than the single-well flows assumed for community space heating requirements.

\section{c. Beneficial Use of Water}

As defined in 46-1-6, beneficial use is "any use of water that is reasonable and useful and beneficial to the appropriator, and at the same time is consistent with the interests of the public in the best utilization of water supplies."

As in all of the statutes concerning water and water rights in the state, no mention is made of water temperature or the potentlally beneficlal use of hot water or other geothermal fluids, vapors, and gases.

Various states have proposed or are drafting proposals for geothermal energy resources acts. The proposals or drafts seen to date define geothermal resources as different from water and minerals. For example, the Alabama proposal includes indigenous steam, hot water, and brines; the same plus other gases that might result from artifically introducing fluids or gases into geothermal formations; heat or other energy found in geothermal formations; and minerals that might be present in solution or association with the geothermal steam, water, or brines.

It is recommended, therefore, that the water and water rights statutes be examined to see if they are adequate to protect the geothermal resources and the rights to them, and thus permit their beneficial use.

\section{Withdrawal from Aquifers}

The 1972 amendment previously clted established a 11mit on the quantity of ground water that can be withdrawn. Since this is stated in terms of the average estimated recharge rate, it is important that more data be collected as soon as possible to improve estimates. ... It may be important also to consider the totality of geothermal resources as mentioned by other states in their proposed legislation, above. 


\section{E. Status of Indian Reservations}

Standing Rock and Cheyenne River Indian reservations lie entirely within the boundaries of the Madison formation. Crow Creek, Pine Ridge, and Rosebud reservations lie partially within the boundaries. The Indians hold "reserved water rights" in the reservations (Winters versus U.S., 1908) and a set of regulations controlling use of reservation waters has been proposed (1977) for enactment by the Secretary of the Interfor. The Impact of these regulations on development of the geothermal resources remains to be determined. 


\section{BIBLIOGRAPHY}

1. Assessment of Geothermal Resources of the United States, 1975 , U.S. Geological Survey Circular 726.

2. R. A. Schoon and D. J. McGregor, Geothermal Potentials in South Dakota, South Dakota Geological Survey Report of Investigation 110, 1974.

3. Program Description, U.S. Energy Research and Development Administration, Division of Geothermal Energy, ERDA-57 UC-66, 1975.

4. Geothermal Applications of the Madison Aquifer System (Pahasapa) In South Dakota, South Dakota School of Mines and Technology, 1976.

5. J. Goguel, Geothermics (English editor, S.P. Clark; translator, A. Rite), McGraw-Hill, 1976.

6. Catalog of Federal Domestic Assistance, Executive Office of the President, Office of Management and Budget, Washington, DC, 1977.

7. South Dakota Compiled Laws 1967 Annotated, Vol. 13, Titles 43 to 46, The Allen Smith Co., Indianapolis, IN.

8. South Dakota Codified Laws Annotated, Vol. 13, 1977 Pocket Supplement, The Allen Smith Co., Indianapolis, IN.

9. L. F. Konikow, Preliminary Digital Model of Ground-water Flow in the Madison Group, Powder River Basin and Adjacent Areas, Wyoming, Montana, South Dakota, North Dakota, and Nebraska, U.S. Geological Survey, Water Resources Investigation 63-75, January 1976.

10. Plan of Study of the Hydrology of the Madison Limestone and Associated Rocks In Parts of Montana, Nebraska, North Dakota, South Dakota, and Wyoming, U.S. Department of the Interior, Geological Survey Report 75-631, 1975. 
GEOTHERMAL SPACE AND HEATING COST MODEL

This Appendix contains the information used to develop a cost model for geothermal residential space heating. The cost model was determined to be a function of these elght basic components: source well cost, reinfection well cost, source transmission cost, reinjection cost, heat exchangers, distribution cost, hookup cost, and conversion cost. The cost of each of the eight basic components is illustrated on the following pages. These component costs are linearly related to population. To represent a typical municipality in western South Dakota a town of 120 residences with a population of 312 (based upon 2.6 people/residence) and distributed along the feedlines in FIg. 2 was used to generate the cost model. 
Average volume per house $\left(\mathrm{ft}^{3}\right)$

Heat $10 s s$ factor (Btu/h-ft ${ }^{3}$ )

Based on: $70^{\circ} \mathrm{F}$ inside design temperature $-20^{\circ} \mathrm{F}$ outside design temperature Insulate roof only

Heat load per residence (btu/h)

Transmission and distribution 1088 (\%)

Future growth (\%)

System design size (Btu/h)

Well flow rate (gpm)

Well temperature $\left({ }^{\circ} \mathrm{F}\right)$

Well depth ( $f t)$
$8960 *$

$7.7^{\dagger}$

$6.9 \times 10^{4}$

10

10

$9.9 \times 10^{6}$

1300

140

3800

* "Geotherma1 Application on the Madison Aquifer System in South Dakota, 6 months Progress Report", South Dakota School of Mines and Technology, March 1977.

† C. Strock, Handbook of Air Conditioning, Heating, and Ventilating, Industrial Press, New York, NY. and

"CASES, Thermal Analysis of a Community, Task B Report", APL/JHU 1tr, August 1977. 
Design parameters

Design heat load $(\mathrm{kcal} / \mathrm{h})$

Well water inlet temperature $\left({ }^{\circ} \mathrm{C}\right)$

Well water outlet temperature $\left({ }^{\circ} \mathrm{C}\right)$

Cold water inlet temperature $\left({ }^{\circ} \mathrm{C}\right)$

Cold water outlet temperature $\left({ }^{\circ} \mathrm{C}\right)$

Overall heat transfer coeffictent

Logarithmic mean temperature $\left({ }^{\circ} \mathrm{C}\right)$

Heat transfer coefficient

Heat exchanger surface area $\left(\mathrm{m}^{3}\right)$
$2.5 \times 10$

60

40

30

55

3050

7.5

2.9

110

0.53

207

320

170

1.0

$5.0-5.3$

140

$4-8$

125

15

Stainless steel Nitri1

Heat Exchanger Cost*

$\$ 17000$

The exchanger is arranged for one pass on each side. Removable covers permit ready access for inspection and cleaning of heat exchange surface. The plate type heat exchanger is extremely reliable and easy to repair. Therefore a backup heat exchanger is not required.

* American Heat Reclaiming Corporation, P.0. Box 860, 1181 U.S. Highway 202S, Somerville, NJ 08876. 


\section{Design parameters}

Design heat load (Btu/h)

Hot water inlet temperature $\left({ }^{\circ} \mathrm{F}\right)$

Hot water outlet temperature $\left({ }^{\circ} \mathrm{F}\right)$

Air inlet temperature $\left({ }^{\circ} \mathrm{F}\right)$

Air outlet temperature $\left({ }^{\circ} \mathrm{F}\right)$

Air velocity (ft/min)

Air flow rate $\left(\mathrm{ft}^{3} / \mathrm{mIn}\right)$

Logarithmic mean temperature $\left({ }^{\circ} \mathrm{F}\right)$
$6.9 \times 10^{4}$

130

93

70

117

600

1485

9.9

$15 \times 24$

8

14

Heating Co11 Cost* $\$ 342$

* Singer, Climate Control Division, 602 Sunnyvale Drive, Wilmington, NC 28401. 


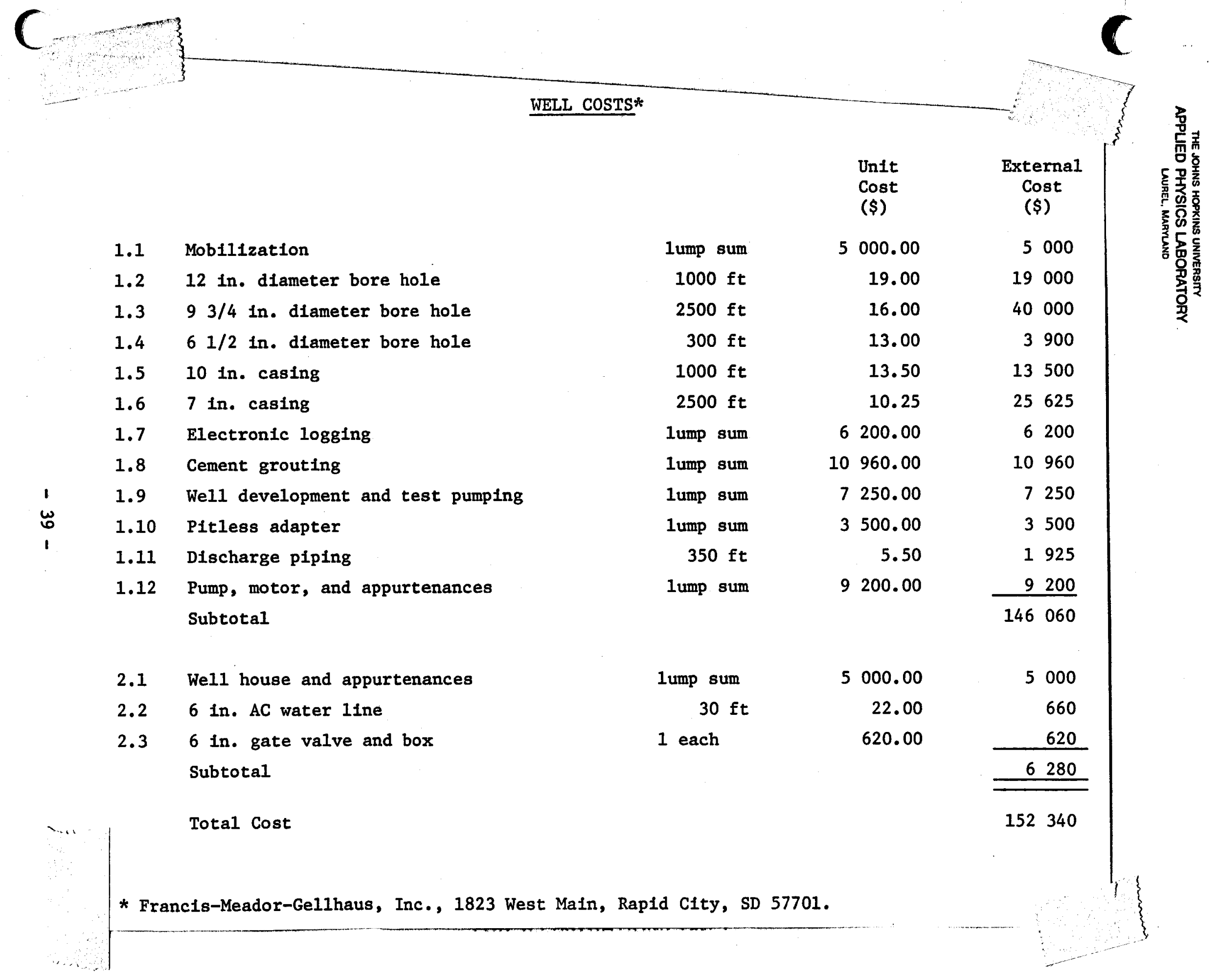


Cement Asbestos Class 150 P1pe

$\begin{array}{cc}\begin{array}{c}\text { Size } \\ (\text { In.) }\end{array} & \begin{array}{c}\text { Pipe Cost* } \\ (\$ / f t)\end{array} \\ 3 & 2.80 \\ 6 & 4.46 \\ 8 & 5.45 \\ 12 & 8.70 \\ 16 & 13.70\end{array}$

1 in. on-site foam insulation $\$ 0.75 / \mathrm{ft}^{2}+$

\begin{tabular}{ll}
\multicolumn{2}{c}{ Installation Costs** } \\
Excavation Costs & 2.63 \\
Back Fill Costs & 0.42 \\
Compact Costs & 6.14
\end{tabular}

Assumptions +

Compact only across roads

Bury pipe $5 \mathrm{ft}$ deep

Feedpipe insulated

Return pipe uninsulated

* 1977 Dodge Guide, McGraw-Hill Information Systems, 1976.

† Telephone Conversation with R. D. Sanders, Idaho National Engineerling Laboratory, Raft River Profect, 20 October 1977.

** C. Engelsman, 1977 Heavy Construction Cost File, Van Nostrand Peinhold Company, 1977. 


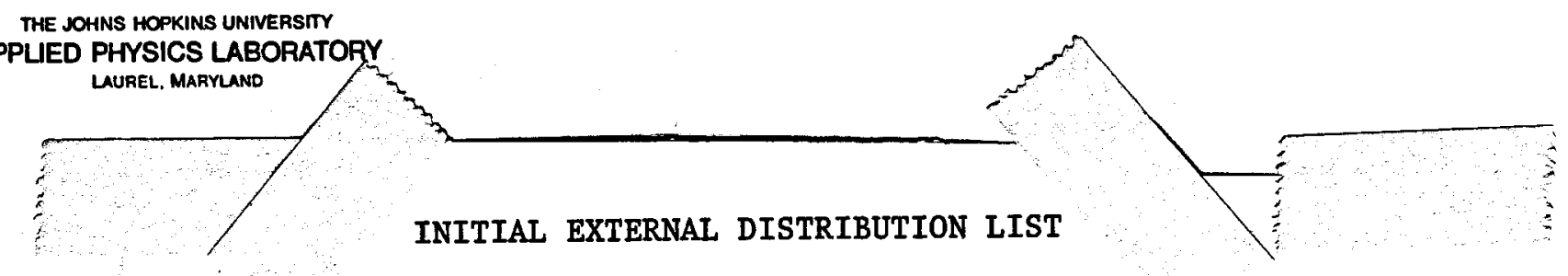

Addressee

Mumber of Coptes

v.s. Department of Energy

Division of Geothermal inergy

20 Masaachusetts

Washington, DC 20545

Attention: J. W. Sallebury

B. G. DiBona

D. B. Lombard

R. B. Ol1ver

M. N. Mansour

R. C. Stephens

I. J. Patk

H. B. Rosenthal

1
1
1
1
1
1
1
1
3
15 coples plus
a camera-ready

พ. D. Gertach, Manager

Geothermal Direct App11cat1ona

EGSG Idaho Inc.

Idaho Falla, ID 83401

U.s. Department of Energy

Idaho Operations office

550 2nd Street

Idaho Falls, ID 83401

copy

Director

10

Energy Office of the State of South Dakota

Plerre, SD 57501

Fifth District Planning and Development Commission Gerald Bergum Comprehenatve Planner

P.0. Dox 640

Pierre, SD 57501

Sixth Dietrict Counc1l of Local Governments

Brian Shorten, Energy Planner

P.0. Box 1586

Rapid C1ty, SD 57709

South Dakota School of M1nes and Technology

Department of Geology and Geological Engineering

Rap1d C1ty, SD 57701

Attention: Dr. J. P. Grles

Department of Matural Resource Development

South Dakota Geological Survey

Sc1ence Center, University

vermil110n, SD 57069

Attent1on: Duncan J. McGregor, State Geologist

WH11am All1son, Admin1strator

St. Mary's Hospital

Pterre, SD 57501

Lewta KleIn, Mayor

Box 27

Box B1der, SD 57719

Wa1ter Stephens, Towa President

Box 82
Buffalo, SD 57720

John McCarthy, Mayor

P.0. Box A

Edgemont, SD 57735

willard Haines, Mayor

Box Is

Patth, SD 57626

1

3

1

1

1

1

1

$$
\text { - }-41-
$$


THE JOHNS HOPKINS UNIVERSITY

APPLIED PHYSICS LABORATORY

LAUREL, MARYLAND

\section{Addressee}

Geneva Parsons, Mayor

303 N River

Bot Springs, SD 57747

Vernon Uhlir, Mayor

P.0. Box 87

radoka, SD 57543

Office of the Mayor

Kyle, SD 57752

John Wheeler

114 3rd street

Mewel1, SD 57760

c. P. BatcheIder, Iown President

Box 186

New Dnderwood, SD 57761

George Crough, Mayor

Box 484

Wa11, SD 57790

G. Stroppe1, Town President Midland, SD 57552

Ed Benton, Chatrman

Fall River County Commisisioner:

Edgemont, SD 57735

Donald Wagner, Cha1rman

Bard1ng County Commissioners

Ralph, SD 57650

Wallace Purze, Chairman

Lawrence County Commissioners

5775

Lead, SD 57754

James Seward, Mayor

722 Main Street

Spearf1ah, SD 37783

Mr. Eddle Clay

- 141 South Ch1cago

Hot Springs, SD 57747

Mr. Buck Schulte

141 E. Illino18

Spearf1sh, SD 57783

Mr. Xen Hudson

406 10th

Bdgemont, SD 57735

Lewrence Brown

Nation Center Newa

Buffalo, SD 57720

Steve Petere

Laurence County Planner

County Courthouse

Deadwood, SD 57732

Dan McMichael.

chool superintendent

Spearf1sh, SD 57783

John Inzler

School Superintendent

Edgemont, SD 57735
Number of Coptes

1

1

1
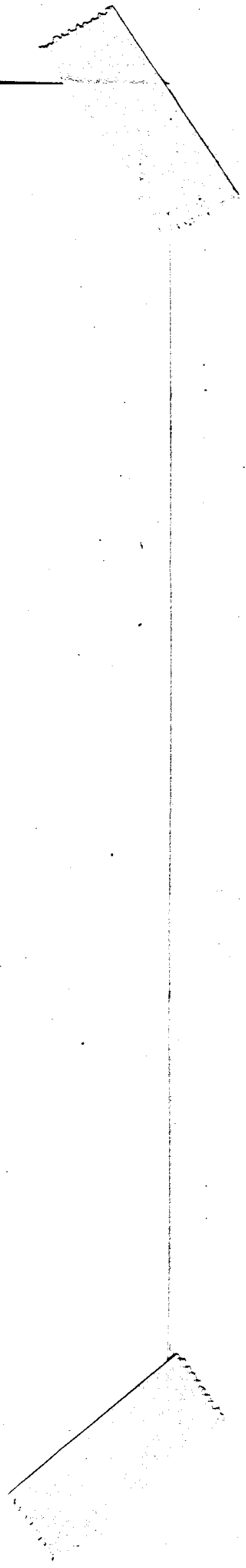
THE JOHNS HOPKINS UNIVERSITY

APPLIED PHYSICS LABORATORY

Laurel, maryland

\section{Addressee}

Jack Issler

Douglas School superintendent

Box Elder, SD 57719

Charles Maxon

School Superintendent

PhIllp, SD 57567

Senator Lynde11 Peterson

Senator Lynded

R.R. 1, Box 21

Rapid C1ty, SD 57701

Senator George McGovern

Unfted States Senate

Washington, DC 20510

Senator James Abourezk

Un1ted Stetes Senate
Washington, DC 20510

\section{Number of Copies}

1

1

1

1

1

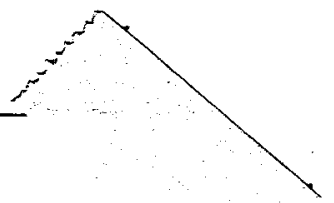

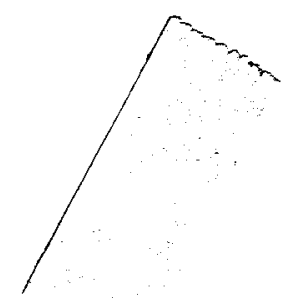

